\title{
Pemphigoid gestationis - a rare dermatosis of the prenatal period. Case report
}

\author{
Pemfigoid ciężarnych - rzadka dermatoza okresu prenatalnego. Opis przypadku
}

Marcin M. Skutil, Ryszard Roztoczyński

Department of Obstetrics and Gynaecology, Voivodeship Hospital, Bielsko-Biała, Poland

Przegl Dermatol 2016, 103, 209-213

DOI: $\mid 0.5$ | |4/dr.2016.60624

\section{KEY WORDS:}

pemphigoid gestationis, herpes gestationis, dermatoses of pregnancy.

SŁOWA KLUCZOWE: pemfigoid ciężarnych, opryszczka ciążowa, dermatozy ciążowe.
ADDRESS FOR CORRESPONDENCE: Marcin Skutil MD, PhD

Ryszard Roztoczyński MD

Department of Obstetrics and Gynaecology

Voivodeship Hospital

101 Armii Krajowej St

43-316 Bielsko-Biała, Poland

phone: +48 692392528

e-mail: skutil@hotmail.com

\section{ABSTRACT}

Introduction. Most skin lesions during pregnancy are associated with hormonal changes. Pemphigoid (herpes) gestationis (PG) is a significant dermatosis of the prenatal period reflecting pathology affecting the mother and fetus.

Objective. The aim of the study was to present a PG case, a rare pregnancy dermatosis with a severe clinical outcome during the postpartum period.

Case report. We present a case of a patient in whom skin lesions with tense blisters occurred at the $40^{\text {th }}$ week of pregnancy. Herpes gestationis - a rare skin disease - was diagnosed based on the clinical picture. During the first days of puerperium, because of an aggressive disease course, the patient was transferred to a reference centre for skin disease treatment. She was given corticosteroid therapy, which brought the expected results.

Conclusions. Pemphigoid gestationis is a rare and serious dermatosis of the prenatal period. Although the treatment of such diseases is the dermatologists' task, obstetricians are responsible for diagnosis and for fetal monitoring considering placental pathology.

\section{STRESZCZENIE}

Wprowadzenie. Większość zmian skórnych w okresie ciąży wiąże się ze zmianami gospodarki hormonalnej. Pemfigoid (opryszczka) ciężarnych jest ważną dermatozą okresu prenatalnego odzwierciedlającą patologię toczącą się w jednostce matczyno-płodowej.

Cel pracy. Przedstawienie przypadku pemfigoidu ciężarnych, rzadkiej dermatozy ciążowej, o ciężkim przebiegu klinicznym w okresie połogu.

Opis przypadku. Przedstawiamy przypadek pacjentki, u której w 40. tygodniu ciąży zaobserwowano zmiany skórne w postaci napiętych pęcherzy, co pozwoliło na podstawie obrazu klinicznego rozpoznać rzadką chorobę skóry, jaką jest opryszczka ciężarnych. W pierwszych dniach połogu ze względu na agresywny przebieg choroby pacjentka została przekazana do ośrodka referencyjnego leczenia chorób skóry. Zastosowana tam terapia glikokortykosteroidami przyniosła zamierzony efekt.

Wnioski. Pemfigoid ciężarnych jest rzadką dermatozą okresu prenatalnego, której terapię prowadzą dermatolodzy, a zadaniem położników jest rozpoznanie choroby i monitorowanie stanu płodu z uwzględnieniem faktu patologii łożyska. 


\section{INTRODUCTION}

The generally accepted classification suggested by Ambros-Rudolph et al. [1] is used to describe skin diseases typical for pregnancy. It includes the characteristics of all types of dermatoses occurring only during pregnancy, i.e. prurigo of pregnancy, polymorphic eruption of pregnancy, pemphigoid gestationis (PG), and intrahepatic cholestasis of pregnancy [1].

Most pregnancy-specific skin conditions have no clinical significance and are associated with physiological insulinemia, as well as an increase in estrogen, progesterone and melanotropin concentrations [2].

Physiological changes in the prenatal period include the following:

- skin pigmentation in the area of the nipples and areola (at about 20 weeks of gestation), underarms, and external genital organs,

- linea nigra,

- melasma (on the forehead, cheeks and the lower jaw),

- connective tissue changes such as striae distensae and skin polyps [3, 4].

The majority of these changes may be reversible, to a certain extent, after delivery. Vascular changes, which are partially caused by increased estrogen levels, are the effect of widening of the blood vessels, their instability, and capillary proliferation occurring on the skin surface. Telangiectasias are more noticeable in women with a fair complexion and occur preferentially around the eyes, on the neck, on the chest, and on the upper limbs.

Exacerbation of these changes occurs in the second trimester of pregnancy and disappears about 2 months after postpartum [5]. Some skin lesions which occur in pregnant women may reflect complications of the prenatal period such as intrauterine growth restriction (IUGR), the risk of premature delivery, or even intrauterine fetal death. Therefore, it is crucial to diagnose dermatoses such as intrahepatic cholestasis of pregnancy or bullous pemphigoid in pregnancy, which is also known as herpes gestationis, to assure proper care of pregnant women. Pemphigoid gestationis occurs relatively rarely, with the estimated incidence of $1 / 700$ to $1 / 50000$ pregnancies, according to different sources. The changes develop most often in the second trimester of pregnancy, and their presence on occasions other than before the delivery is rather uncommon [6].

The first changes occur on the skin in the navel area in the form of urticaria with papules and plaques, developing into a vesiculobullous rash during disease progression, and then on the skin of the trunk, limbs, palms and soles. After a few weeks, the initial skin rash evolves into tense blisters, large in diameter.
Pemphigoid gestationis is etiologically an autoimmune disease, and its association with HLA-DR3 and HLA-DR4 haplotypes has been proven. Due to the fact that early clinical diagnosis presents a certain challenge, skin biopsy is helpful but direct immunofluorescence test (DIF) is necessary to make the final diagnosis. The material undergoes pathomorphological examination and the DIF test is performed. In a typical course of the disease, cell degeneration of the stratum basale (the cause of blistering) and epidermal spongiosis are found in microscopic analysis. Deposits of the $\mathrm{C} 3$ component of complement along the basement membrane are observed in the DIF test. Complement binding IgG antibodies occur in half of the affected patients [7].

The indirect immunofluorescence test (IIF) of blood or the fluid obtained from the changes shows the presence of IgG antibodies directed against bullous pemphigoid antigen 2, which is located on hemidesmosomes along the basement membrane [8].

Treatment during pregnancy relies on reduction of change intensification and is most often individualized. If the locally acting drugs are ineffective, intravenous pharmacotherapy should be initiated, the base of which, apart from histamine antagonists, are corticosteroids. Ciclosporin, which seems safe for the fetus, has also been approved for PG treatment, but it cannot be used during lactation $[9,10]$. Prednisolone, the safest of the corticosteroids, is subject to almost complete placental metabolism [11].

The disease has periods of remission and exacerbation. Regression of the changes is observed predominantly in the pre-delivery period. However, blistering is present in about $75 \%$ of the patients during delivery. Skin changes disappear after about 2-6 weeks postpartum in the majority of affected patients. Dermatosis is a recurrent disease; it can occur in subsequent pregnancies and run a more severe course. Menstruation and hormonal contraception are among other provoking factors [12]. A correlation has been found between the presence of PG and IUGR. Data on such correlation are of low diagnostic value, but they indicate the need for careful fetal monitoring in that group of patients [13].

Moreover, inflammatory processes in the skin also affect the placental tissue. They are probably the reason for IUGR and can lead to all the consequences associated with this disorder [14].

A similar rash occurring immediately after the delivery can be observed in about $10 \%$ of infants born to mothers with $\mathrm{PG}$, as a result of passive transfer of the antibodies from the mother [15]. Pemphigoid gestationis occurs with other autoimmune diseases such as Graves' disease. Therefore, thyroid function tests are recommended in this group of patients [16]. 


\section{CASE REPORT}

The patient, at 37 weeks of gestation, was admitted to the Department of Pathology of Pregnancy due to intense skin pruritus and rash around the navel. Based on the data gathered during the interview, the course of pregnancy was assessed as physiological. In the differential diagnosis of the above ailments, intrahepatic cholestasis of pregnancy and polymorphic eruption of pregnancy were distinguished. In the performed laboratory tests, significant aberrations were not observed. In the IF test an elevated titer $(1: 160)$ of antinuclear antibody with a coarse speckled pattern was detected.

Second-generation antihistamines were administered due to persistent pruritus, improving the general condition of the patient. Fetal ultrasound (biophysical profile, Doppler ultrasound test) was normal. The patient was discharged from the hospital.

The patient was readmitted at 40 weeks of gestation due to intensified pruritus and the presence of an erythematous papular rash on the abdomen and small blisters on the upper limbs (Figures 1 A, B). Pemphigoid gestationis was suspected after consultation with a dermatologist. As the disease is associated with placental pathology, labor was induced. Cesarean section was performed due to abnormal cardiotocography. A male infant (weight 3380 g, Apgar scores of 9) was delivered.

A few hours after the operation, progression of skin lesions, with intense pain and pruritus, was observed (Figure 2). Systemic corticosteroid therapy (prednisone $30 \mathrm{mg} /$ day; dexamethasone $12 \mathrm{mg} /$ day), calcium carbonate and antibiotic therapy resulted in slight alleviation of the symptoms. Lactation was inhibited. During postoperative day 1, blisters ( $1 \mathrm{~cm}$ in diameter) occurred and were located mainly on the medial thighs and the forearms (Figures 3 and 4 A, B). The therapy proved ineffective, and therefore, on postoperative day 5 , the patient was transferred to the reference center for treating skin diseases. Herpes gestationis was clinically diagnosed at the Department of Dermatology. Skin biopsy was performed and treatment including methylprednisolone (48 mg/day for 4 days), cefuroxime ( $3 \mathrm{~g} /$ day for 10 days), antianemic drugs and anticoagulants was initiated. The IIF test was negative.

Skin lesions were treated topically with hydrocortisone, oxytetracycline hydrochloride, and clobetasol propionate, resulting in gradual regression of lesions and general improvement of the patient's condition. The puerperium during the dermatosis treatment was otherwise uneventful. On day 13 of hospitalization, the general condition of the patient was good and she was discharged from hospital. The patient was advised to continue treatment with
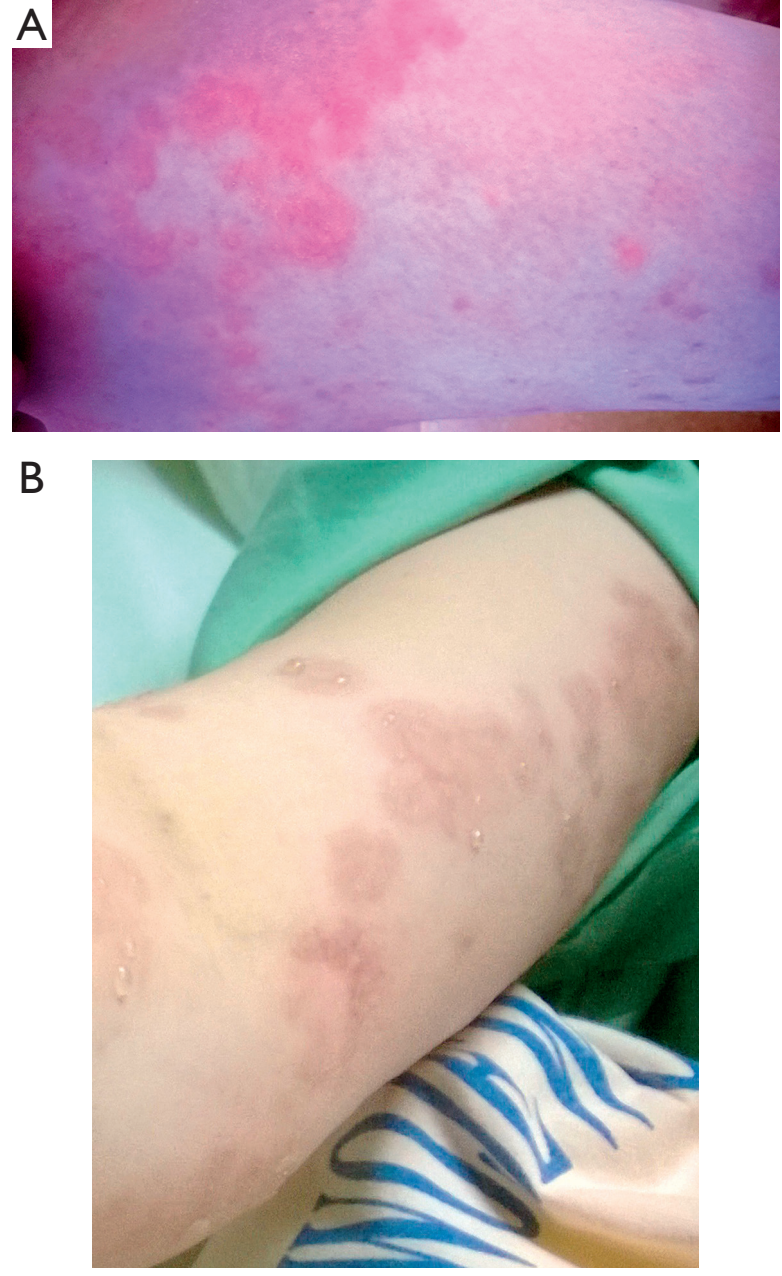

Figure I A, B. Initial lesions

Rycina I A, B. Zmiany pierwotne

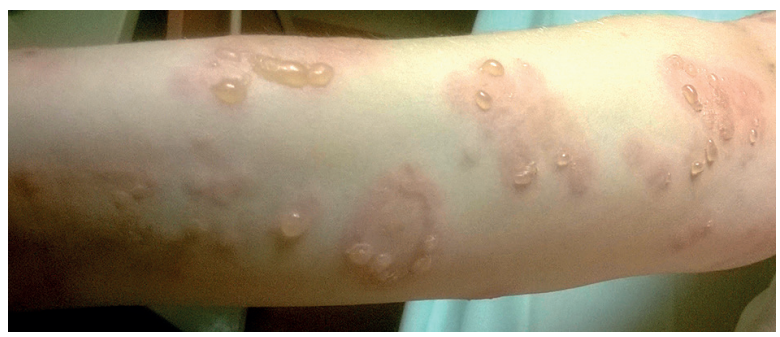

Figure 2. Small blisters on the upper limbs

Rycina 2. Niewielkie pęcherze na kończynach górnych

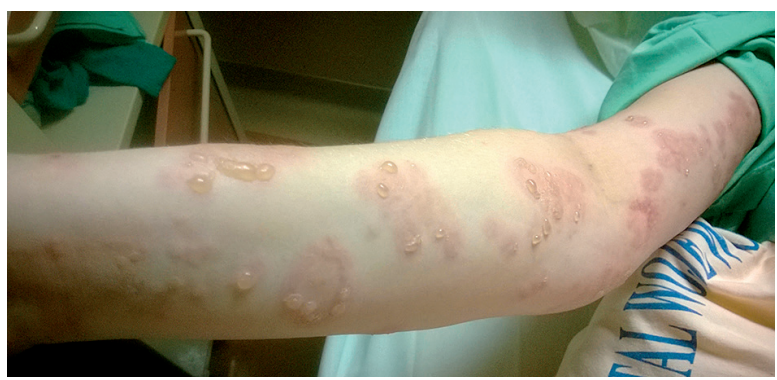

Figure 3. Blisters and lesions with a target sign

Rycina 3. Pęcherze i zmiany typu „tarcza strzelnicza” 

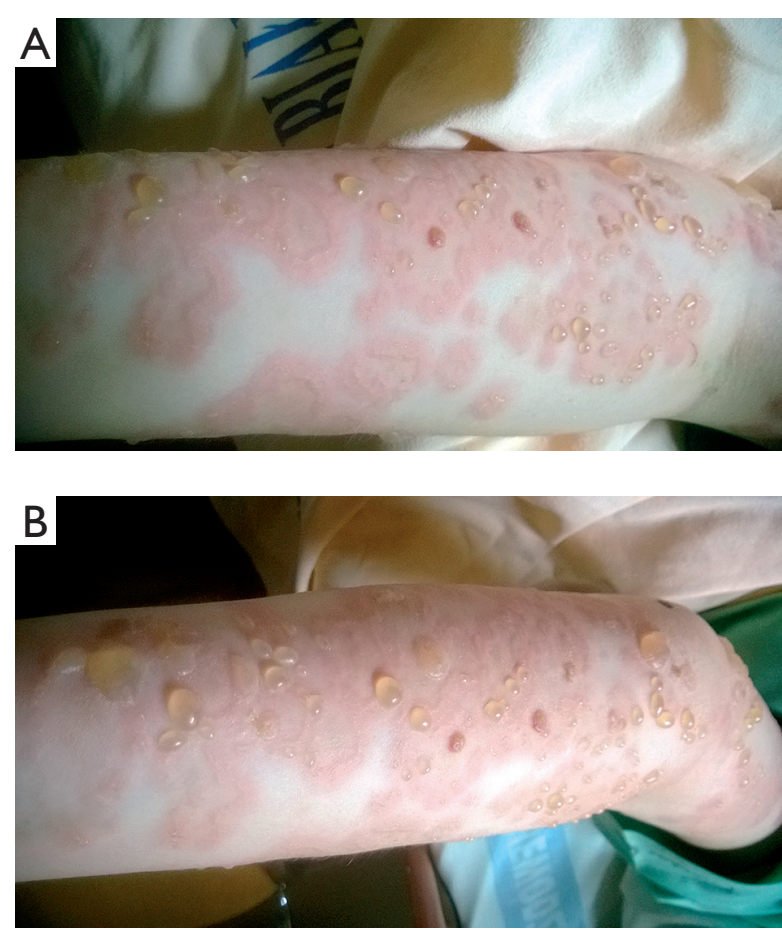

Figure 4 A, B. Severe skin lesions with tense blisters

Rycina 4 A, B. Nasilone zmiany z obecnościq̨ napiętych pęcherzy

methylprednisolone for 5 days, with gradual dose reduction under ambulatory control of the clinical state. Antianemic drugs and topical application of chloramphenicol ointment were also recommended. Histopathological results of the biopsy confirmed the initial clinical diagnosis, i.e. herpes gestationis. IgG and $\operatorname{IgA}$ deposits at the basement membrane zone (+BMZ) and in the same location abundant deposits of complement component $\mathrm{C} 3$ (+++BMZ) were found in tissue examination by DIF test in the biopsy of healthy skin near the skin lesion.

\section{DISCUSSION}

Skin lesions, which occur in a normal pregnancy, are usually associated with physiological insulin resistance and hyperestrogenism [2]. Also, they are sometimes symptoms of pregnancy-specific diseases.

Pemphigoid gestationis, which frequently occurs with IUGR, is an inflammatory process occurring not only in the skin but also in the trophoblastic tissue. The IUGR is defined as fetal growth below the expected genetic potential. It results in a significant increase in perinatal mortality and vascular complications such as stroke and myocardial infarction in adulthood. Insufficient fetal development in the dermatosis is associated with placental vascular pathology. The inflammation in the trophoblastic tissue can lead to infarcts and calcification, which can inhibit nutrient exchange between the mother and the fetus [17]. In the present case, early stages of the dermatosis were not typical and were suggestive of intrahepatic cholestasis of pregnancy. They resolved after treatment with ursodeoxycholic acid, which not only alleviates clinical symptoms but also reduces the risk of fetal complications [18]. Exacerbation of the disease occurred just after delivery and took an aggressive course. The symptomatic treatment proved ineffective. Therapy with high doses of steroids was initiated in the reference center for treatment of dermatosis and brought the expected, satisfactory effects. Corticosteroids must be used carefully because they can increase the risk of osteoporosis in pregnant patients. Therefore, it is recommended to conduct the symptomatic treatment using topical therapy. In order to alleviate the symptoms, first-generation or second-generation antihistamines such as cetirizine or loratadine (which are classified in category B according to the FDA) should be administered. The only side effect of loratadine may be rarely occurring hypospadias [19-23].

In case of an aggressive course of disease, individually adjusted prednisolone dosing should be administered (it is most often $0.5 \mathrm{mg} / \mathrm{kg} /$ body weight reducing the dose by $5 \mathrm{mg}$ every 3 days), because it is safe for the fetus and entirely metabolized by the human placenta [15]. If escalating the dose above $7.5 \mathrm{mg}$ is necessary, it is recommended to monitor kidney functions and blood pressure. Since more severe disease symptoms can occur before delivery, it is recommended to increase the dose 7 days before the due date. Broad-spectrum antibiotic therapy should be implemented. Ciclosporin is a safe medication in the therapy for pregnant women [9] but it is contraindicated during lactation due to possible immunosuppressive activity and possible induction of neutropenia [10]. During puerperium immunosuppressive medications can be used and plasmaphoresis can be performed [24].

The patient remains under dermatological and gynecological ambulatory care in a hospital outpatient clinic. Pruritus occurs in the area of the navel and on the medial compartment of both thighs before and during menstruation. Neurotic excoriations on the skin have been noted.

\section{CONFLICT OF INTEREST}

The authors declare no conflict of interest.

\section{References}

1. Ambros-Rudolph C.M., Müllegger R.R., Vaughan-Jones S.A., Kerl H., Black M.M.: The specific dermatoses of pregnancy revisited and reclassified: results of a retrospective two-center study on 505 pregnant patiens. J Am Acad Dermatol 2006, 54, 395-404. 
2. Męczekalski B., Podfigurna-Stopa A., Czyżyk A., Katulski K.: Endokrynologiczne zaburzenia czynności jajników a ciąża. [in:] B. Męczekalski (ed.). Endokrynologia ciąży. Wydawnictwo Lekarskie PZWL, Warszawa 2012, 241.

3. Wong R.C.: Physiologic skin changes in pregnancy. [in:] M. Harahap, R.C. Wallach (ed.). Skin changes and diseases in pregnancy. New York, 1996, 37.

4. Martin A.G., Leal-Khouri S.: Physiologic skin changes associated with pregnancy. Int J Dermatol 1992, 31, 375-378.

5. Esteve E., Saudeau L., Pierre F., Barruet K., Vaillant L., Lorette G.: Physiological cutaneous signs in normal pregnancy: a study of 60 pregnant women. Ann Dermatol Venerol 1994, 121, 227-231.

6. Maharajan A., Aye C., Ratnavel R., Burova E.: Skinseruptions specific to pregnancy: an overview. Obstet Gynecol 2013, 15, 233-240.

7. Kint A., Geerts M.L., Vanneste B., De Cuyper C.: Herpes gestationis. A histological and electron microscopic study. Ann Dermatol Venerol 1980, 107, 1133-1142.

8. Zilikens D.: Pemphigoid gestations: recent advances. JEADV 2003, 17 (Suppl s3), 7.

9. Branche J., Cortot A., Bourreille A., Coffin B., Vos M., Saussure P. i inni: Cyclosporine treatment of steroid-refractory ulcerative colitis during pregnancy. Inflamm Bowel Dis 2009, 15, 1044-1048

10. American Academy of Pediatrics: The transfer of drugs and other chemicals into human milk. Pediatrics 2001, 108, 776-7812.

11. Murphy V.E., Fittock R.J., Zarzycki P.K., Delahunty M.M., Smith R., Clifton V.L.: Metabolism of synthetic steroids by the human placenta. Placenta 2007, 28, 39-46.

12. Vaughan Jones S.A., Hern S., Nelson-Piercy C., Seed P.T., Black M.M.: A prospective study of 200 women with dermatoses of pregnancy correlating clinical findings with hormonal and immunopathological profiles. Br J Dermatol $1999,141,71-81$

13. Chi C.C., Wang S.H., Charles-Holmes R., Ambros-Rudolph C., Powell J., Jenkins R. i inni: Pemphigoid gestations: early onset and blister formation are associated with adverse pregnancy outcomes. Br J Dermatol 2009, 160, 1222-1228.

14. Huilaja L., Mäkikallio K., Sormunen R., Lohi J., Hurskaien T., Tasanen K.: Gestational pemphigoid: placental morphology and function. Acta Derm Venereol 2013, 93, 33-38.

15. Black M.M., Ambros-Rudolph C., Edwards L., Lynch P.: Obstetric and gynecologic dermatology. 3rd ed. Mosby Elsevier, London 2008.

16. Semkova K., Black M.: Pemphigoid gestations: current insights into pathogenesis and treatment. Eur J Obstet Gynecol Reprod Biol 2009, 145, 138-144.

17. Grand'Maison S., Durand M., Mahone M.: The effects of ursodeoxycholic acid treatment for intrahepatic cholestasis of pregnancy on maternal and fetal outcomes: a meta-analysis including non-randomized studies. J Obstet Gynaecol Can 2014, 36, 632-641.

18. Khaliq A., Li XF., Shams M., Sisi P., Acevedo C.A., Whittle M.J., et al.: Localisation of placenta growth factor (PIGF) in human term placenta. Growth Factors 1996, 13, 243-250.

19. Gilbert C., Mazzota P., Loebstein R., Koren G.: Fetal safety of drugs used in the treatment of allergic rhinitis: a critical review. Drug Saf 2005, 28, 707-719.

20. Schatz M., Zeiger R.S., Harden K., Hoffman C.C., Chilingar L., Petitti D.: The safety of asthma and allergy medications during pregnancy. J Allergy Clin Immunol 1997, 100, 301-306.

21. Seto A., Einarson T., Koren G.: Pregnancy outcome following first trimester exposure to antihistamines: meta-analysis. Am J Perintol 1997, 14, 119-124.

22. Giloba S.M., Strickland M.J., Olshan A.F., Werler M.M. Correa A.: National Birth Defects Prevention Study. Use of antihistamine medications during early pregnancy and isolated major malformations. Birth Defects Res A Clin Mol Teratol 2009, 85, 137-150.

23. Weber-Schoendorfer C., Schaefer C.: The safety of cetirizine during pregnancy. Reprod Toxicol 2008, 26, 19-23.

24. Briggs G.G., Freeman R.K., Yaffe S.J.: Drugs in pregnancy and lactations. 7th ed. Lippincot Williams \& Wilkins, Philadelphia, 2005.

Submitted: $22 \times 2015$

Accepted: 20 V 2016 